\title{
Foreign Direct Investment, Institutions and Economic Growth: Evidence from the MENA Region
}

\author{
Mariem Brahim ${ }^{1}$ and Houssem Rachdi ${ }^{2, *}$ \\ ${ }^{1}$ Faculté des Sciences Economiques et de Gestion: University of Paris XIII, France \\ ${ }^{2}$ Faculté des Sciences Juridiques, Economiques et de Gestion: University of Jendouba, Tunisia
}

\begin{abstract}
Few scientific papers treat the role of institutions on the relationship between foreign direct investment (hereafter FDI) and economic growth. In the existing literature, the FDI effects on growth are not easy to understand. Mixed findings, both theoretical and empirical, have been provided on this issue by the academic research. The first contribution of this study is an analysis of how institutions quality affects FDI-growth nexus. The second contribution is the use of the Panel Smooth Transition Regression (PSTR) modeling because the nexus between FDI and economic growth is nonlinear and depends on specific national factors especially institutions quality. This method helps to account for a change of regime in the effects of FDI on economic growth. The major finding of this study is that the effect of FDI on economic growth is conditional to the development of institutions in MENA countries. Empirically, on a sample of 19 MENA countries over the period 1984-2011, we found that only countries with good institutions can exploit the advantages of FDI on growth.
\end{abstract}

Keywords: Economic growth, FDI, institutions quality, PSTR, MENA countries.

\section{INTRODUCTION}

The liberalization of the economy is necessary for better mobilization of savings, diversification of risks to lead to growth. Most developing countries eased restrictions on FDI and offered many tax incentives to attract foreign capital. Not surprisingly, thus, an important number of academic researchers have examined the relationship between FDI and economic growth because FDI is considered one of the most stable components of capital flows and is identified as a vehicle of technology transfer that improves factors productivity. FDI is often regarded as an important way and plays an ambiguous role in contributing to economic growth. Literature suggests that FDI can stimulate economic growth only under certain particular policy hypotheses, especially, the quality of institutions. Institutions quality is regarded as key factor of economic growth. Fatih Ahmed (2010) highlights that institutional framework supports markets, facilitates economic exchange, defines and protects rights, registers and enforces contracts. Proficient and established institutions provide an appropriate environment for growth-enhancing activities like investment, innovation, and entrepreneurship, and permit society to function smoothly as individuals are able to invest their time in fruitful activities.

The quality of institutions in host countries affects growth directly through influencing total factor

\footnotetext{
*Address correspondence to this author at the Faculté des Sciences Juridiques, Economiques et de Gestion: University of Jendouba, Tunisia;

Tel: +21678600299; Fax: +21678601176; E-mail: rachdih@uvica.ca

JEL Classification: F 36, F 43, C24.
}

productivity, and indirectly through influencing investment. When institutions are weak, the legal system doesn't work effectively and seems to be an impediment to attract FDI. The share of FDI is lower in countries with weak institutions. In contrast, high quality institutions secure foreigners against the risk of expropriation and increase the amount of FDI. We can point out that FDI and institutions go hand in hand and that FDI is fostered by the effectiveness of institutions. The role of institutions quality has not received considerable and growing attention in literature. This paper fills this gap in examining this impact on economic growth (Bénassy-Quéré et al. 2007; Kohler 2010, Jude and Levieuge 2013).

The main purpose of our paper is to explore what is beyond the role of institutions as a determinant of FDI inflows and consider institutional quality as a feature of absorptive capacity. Though a limited theoretical contribution regarding the interpretation and analysis of the relationship between the growth of FDI and the quality of institutions, we tried to rise up significant arguments that can support and maintain the hypothesis of the heterogeneous effect on FDI growth based on the quality of institutions. We will analyse in concomitant manner FDI and institutions. To our knowledge, no attempts have so far been made to investigate the relationship between FDI, institutions and economic growth in the MENA region. This first study contributes to the existing literature in several ways. Firstly, motivated by the benefits generated by FDI that can intensify when institutions quality improves, we revisit the nexus between FDI and institutions in generating outcome by applying a PSTR 
in all MENA countries as the potential for institutional heterogeneity to expect the existence of a threshold level influencing the FDI-economic growth nexus. Secondly, the advantage of PSTR over other alternative models (fixed effect, random effect and GMM in system) is that the estimation of the thresholds is endogenous.

The rest of this paper is structured as follows: Section 2 provides a brief review of the literature and discusses the relationship between FDI, institutions and economic growth. Section 3 describes the empirical methodology and reports estimations results. Section 4 concludes.

\section{RELATED LITERATURE}

The main channel of the FDI influence on economic growth is the productivity enhancement that the foreign affiliates spread and share with the domestic organizations. Stakeholders' relationships and convergences play a crucial role in occurring spillovers, increasing firm's competitive advantages, and labor turnover. Foreign investment intensifies competition in the industry it enters, both by increasing the number of competitors, and by introducing new ways to compete (Blomström and Kokko, 2003; Driffield and Love, 2007). Local firms may adapt their strategies to counter the challenge, and thus to raise their competitive edge (Bowen and Wiersema, 2005).

Several researches have investigated the relationship between the Institutions' quality and their impact on the FDI. This impact was analyzed on the basis of different methodologies, time spans, and geographical. The first line of action of FDI on economic growth takes place through Institutional quality and productivity spillovers, the core influence of FDI on economic growth consists of productivity improvements from foreign affiliates to domestic firms. According to North (1990), the analysis of the institutions helps to clarify their economic performance based on their organizational behavior and change management. The majority of researches asserted that the "Well-functioning institutions" represent a crucial factor of attracting FDI. Even if the concept of institutions' quality was not as important as it is today, the current situation allowed to report the necessity of better promoting and organizing the field to reach the objectives assigned by institutions to enhance their capacity and capability. In this project we are trying to diagnoses the present, and build the future to explain and understand the realities of what really works and what is the correlation between the FDI growth and the quality of institutions. North (1990) contends that any theory on institutions must be based on human behaviors since all institutions are created and changed by humans.

Daude and Stein (2007) demonstrate that inward FDI is deeply influenced by the quality of institutions. Busse and Hefeker (2007) find that governmental stability; internal and external conflict; ethnic tensions; law and order; democratic accountability of government; and the quality of bureaucracy are highly significant in determining FDI inflows in the sample of 83 developing countries. On the other side, Meon and Sekkat (2004) investigated the impact of the quality of institutions on manufactured exports and FDI in MENA countries. Their results show that a low level of corruption and high level of bureaucracy contribute significantly to the firms' decision related to invest abroad. Daniele and Marani (2007) analyzed the factors of FDI towards the MENA countries where the growth of FDI flows proved to be notably inferior to the one recorded in the European and Asian economies, especially China and India. They suggest that MENA require deep institutional reforms in order to improve the attractiveness in terms of FDI.

Accordingly, Guerin and Manzocchi (2009) put forward that, in 1992-2004, democracy positively affected the amount of FDI flows; while most empirical studies show that corruption affects negatively the amount of FDI flows. Wei $(1997,2000)$ stipulates that when multinationals are not sure about the host country's corruption, this will negatively affect their choices for FDI locations. This idea is supported by the empirical tests of Voyer and Beamish (2004), Habib and Zurawicki (2002). In addition, Onyeiwn (2003) has also tried to study the effect of corruption on FDI in the MENA region. As a matter of fact, local firms hinder any foreign entry if they have sound reasons for their refusal (Chen et al. 2007). When countries receive foreign investment, competition in industry will intensify as not only the number of competitors will increase but also new ways of competitiveness will develop (Dunning, 1988). This competition will urge local firms to enhance their strategies to face the challenge and therefore to raise their competitive edge (Bowen and Wiersema, 2005). It is worth noting that the local firms' reaction to competition depends on their motivation and thus the incentives they face. The latter depend on the institutional framework and in particular the effectiveness of both domestic and institutional markets 
(North, 1990; Peng et al. 2008) and the national innovation system (Nelson, 1993; Lundvall et al. 2002). Copy rights and research and development protection processes highly affect the quality of institutions and deeply influence the technology transfer from the main office to affiliates overseas. Following the same logic than Busse and Hefeker (2007) and Ali et al. (2010), we argue that institutions can increase and optimize not only the FDI quantity, but also their quality. Instability and change inside institutional environment threaten the organization progress and increase risks. Low institutional quality will be followed by a lowtechnology, resource exploiting and limited potential growth of FDI.

According to Mody and Murshid (2005), financial integration allows agents to optimize their investment portfolios, and this may not involve increasing domestic investment. Their results show that the surge in capital flows during the 1990s was driven largely by this diversification motive. Countries with better policies did have greater success in absorbing foreign inflows. At least in part, this could be because improved policies raised the marginal product of new investments, while at the same time they created an environment conducive for the diffusion of new technologies and ideas intrinsic to foreign capital. Improved policies probably also reduced the risk of holding domestic assets, which in turn, by discouraging capital outflows, would have further enhanced the relationship between capital flows and investment.

Based on an annual aggregate data presenting 46 developing countries, Morrissey and Udomkerdmongkol (2012) tried to analyze the FDI and their impact on the domestic private investment. They investigated on alternative elements of governance and their different impacts on FDI and private investment relationship. According to them, good governance is the key factor that attracts greater total investment. The extent of crowding out is highly dependent on the degree of governance transparency and trust. Political stability and absence of corruption are the most stimulated elements of FDI and the core dimension of building trust and confidence in the business environment. They demonstrated how an increase in FDI has the greatest effect on reducing private investment while it leads to a significant increase of total investment) inside political stable regimes.

We argue that institutions may reduce the crowdingout effect by encouraging foreign investment in new fields, where domestic competition has lesser density. Supply chain designing is also crucial and can affect the performance of the organization when taking advantage of the entrance of new suppliers into the market. The interaction between foreign and domestic investment can also occur through the financial market, especially in the case of mergers and acquisitions. For Méon and Sekkat (2008), the control of corruption led to a positive and significant growth of the manufactured goods export within political stability.

\section{ECONOMETRIC FRAMEWORKS AND MAJOR FINDINGS}

\subsection{Data and Model}

This section describes the econometric approach to evaluate the link between FDI, institutions and economic growth. The empirical evidence on the effect of FDI, institutions on economic growth is less conclusive. Our empirical study is based on a sample of 19 countries (Algeria, Bahrain, Egypt Arab Rep, Irak, Iran, Islamic Rep, Israël, Jordan, Kuwait, Lebanon, Libya, Morocco, Oman, Qatar, Saudi Arabia, Sudan, Syrian Arab Republic, Tunisia, Turkey and United Arab Emirates) over the period 1984-2011.

PSTR models have better fitting performance and predictability than linear models and also estimates the smoothness of the transition through regimes. The basic PSTR model with two extreme regimes is defined as:

$y_{i t}=\mu_{\mathrm{i}}+\alpha_{0}^{\prime} \mathrm{x}_{\mathrm{it}}+\alpha_{1}^{\prime} \mathrm{x}_{\mathrm{it}} \mathrm{G}\left(\mathrm{z}_{\mathrm{it}-\mathrm{d}} ; \gamma, c\right)+\varepsilon_{i t}$

Where $\mathrm{i}=1 \ldots, \mathrm{N}$, and $\mathrm{t}=1, \ldots, \mathrm{T}$. $\mathrm{N}$ and $\mathrm{T}$ denote the cross-section and time dimensions of the panel, respectively. $y_{i t}$ is a dependent variable and $x_{i t}$ is a Kdimensional vector of time-varying exogenous variables. $\mu_{\mathrm{i}}$ represents the fixed individual effect. $\mathrm{G}\left(\mathrm{z}_{\mathrm{it-d}} ; \gamma, c\right)$ is the transition function bounded between 0 and 1 and dependent on the transition variable $z_{i t}$, which can be an exogenous variable or a combination of the lagged endogenous one. $d$ is the delay of transition (the optimal lag length for the transition variable). $y$ is the slope parameter, describing the slope of the transition function. $\mathrm{c}$ is the threshold or location parameter. $\mathrm{Y}$ and $\mathrm{c}$ are endogenously estimated. $\varepsilon_{i t}$ is a residual term $\left(\varepsilon_{i t}\right.$ i.i.d $\left.\left(0, \sigma_{\varepsilon}^{2}\right)\right)$. In a panel framework, the logistic or exponential specification can be used for the transition function: 
Logistic function:

$\mathrm{G}\left(\mathrm{z}_{\mathrm{it}-\mathrm{d}} ; \gamma, c\right)=\left[1+\exp \left(-\gamma \prod_{j=1}^{m}\left(z_{i t-d}-c_{j}\right)\right)\right]^{-1}$

Exponential function:

$\mathrm{G}\left(\mathrm{z}_{\mathrm{it}-\mathrm{d}} ; \gamma, c\right)=1-\exp \left(-\gamma \prod_{j=1}^{m}\left(z_{i t-d}-c_{j}\right)^{2}\right)$

Wherey $>0$ and $c_{1} \leq c_{2} \ldots \ldots . . \leq c_{m} . \mathrm{m}$ is the number of location or threshold parameters. When $\mathrm{Y} \rightarrow \infty$, the PSTR converges towards a panel transition regression (PTR) model. On the contrary, when $\mathrm{\gamma \rightarrow 0}$, the transition function is constant and the PSTR estimation becomes a panel with fixed effects. Gonzales et al. (2005) argued that from an empirical point of view, it is sufficient to consider only the cases of $m=1$ or $m=2$ to capture the non linearities due to regime switching.

In this study, we will use the institutional variable as a transition variable $z_{i t-d}$, the PSTR model is defined as follow:

$$
\begin{aligned}
& G D P_{i t}=\mu_{\mathrm{i}}+\alpha_{0}^{\prime} \mathrm{FDI}_{\mathrm{it}}+ \\
& \alpha_{1}^{\prime} \mathrm{FDI}_{\mathrm{it}} \mathrm{G}\left(\mathrm{z}_{\mathrm{it}-\mathrm{d}} ; \gamma, c\right)+\delta^{\prime} x_{i t}+\varepsilon_{i t}
\end{aligned}
$$

Where $x_{i t}$ is k-dimensional vector of growth (inflation, trade, commodity price, government consumption, domestic investment population and bilateral exchange rate), $d$ is the delay of transition. To resolve the endogeneity bias of FDI, we use $\mathrm{Ng}$ and Perron (1995) test to determine the optimal lag length of the FDI $\left(\varepsilon_{i t}\right.$ i.i.d $\left.\left(0, \sigma_{\varepsilon}^{2}\right)\right)$.

$$
\begin{aligned}
& G D P_{i t}=\mu_{\mathrm{i}}+\sum_{j=1}^{p} \alpha_{j} \mathrm{FDI}_{\mathrm{it}-\mathrm{j}}+ \\
& \left\{\left(\sum_{j=1}^{p} \alpha_{j}^{\prime} \mathrm{FDI}_{\mathrm{it}-\mathrm{j}}\right) * \mathrm{G}\left(\mathrm{z}_{\mathrm{it}-\mathrm{d}} ; \gamma, c\right)\right\}+\delta^{\prime} x_{i t}+\varepsilon_{i t}
\end{aligned}
$$

The final model to estimate in this study is:

$$
\begin{aligned}
& G D P_{i t}=\mu_{\mathrm{i}}+\left(\alpha_{0}+\alpha_{1} \mathrm{FDI}_{\mathrm{it}-1}\right)+ \\
& \left(\alpha_{0}^{\prime}+\alpha_{1}^{\prime} \mathrm{FDI}_{\mathrm{it}-1}\right)^{*} \mathrm{G}\left(\mathrm{z}_{\mathrm{it}-\mathrm{d}} ; \gamma, c\right)+\delta^{\prime} x_{i t}+\varepsilon_{i t}
\end{aligned}
$$

Where: GDP is the real GDP per capita growth. FDI is the foreign direct investment. $X$ : is the vector of explanatory variables (inflation, trade, government consumption, domestic investment, population, commodity price index and bilateral exchange rate). INS: We use 12 measures of institutions including government stability, socioeconomic conditions, investment profile, law and order, corruption, internal conflicts, external conflicts, democratic accountability military in politics, religion in politics bureaucracy quality and ethnic tension. $\varepsilon$ is the error term. Real GDP per capita growth, FDI, inflation, trade, government consumption, domestic investment and population are taken from the World Bank (World Development Indicators), Exchange rate is taken from Datastream, oil price material from UNCTAD and the institutional variables are taken from the International Country Risk Guide Database (ICRG). A definition and abbreviations of all the variables and their sources is provided in Appendix 1.

Table 2 contains the descriptive statistics for the variables that investigate the effect of FDI and institutions on growth. It presents means, standard deviation, minimums and maximums of all the variables.

Table 3 presents the correlation coefficients of the institutional variables used in our models. This symmetric matrix measures correlation on a scale with 1 indicating a perfect positive correlation, zero no correlation and -1 perfect negative correlation. Results indicate that all correlation coefficients are lower than

Table 1: Optimal Lag Length of the FDI

\begin{tabular}{|c|c|c|c|}
\hline Lag length of the FDI & Coefficient & T-stat & p-value \\
\hline \hline Constant & $1.527^{* * *}$ & 5.165 & 0.000 \\
\hline FDI (1) & $0.702^{* * *}$ & 10.015 & 0.000 \\
\hline Ljung-Box Q-Statistics & Lags & $\mathbf{x}^{2}$-Stat & $\mathbf{p}$-value \\
& Lag (6) & $14.385^{\star *}$ & 0.025 \\
& $\operatorname{Lag}(12)$ & $24.727^{* *}$ & 0.016 \\
& $\operatorname{Lag}(18)$ & $28.699^{* *}$ & 0.052 \\
& $\operatorname{Lag}(24)$ & $34.804^{*}$ & 0.071 \\
\hline
\end{tabular}

${ }^{1}$ The coefficient of the second lag of FDI is insignificant at the level of $10 \%$.

${ }^{* *},{ }^{* * *}$ and ${ }^{*}$ indicate statistical significance at the $5 \%, 10 \%$ and $1 \%$ level. 
Table 2: Summary Statistics

\begin{tabular}{|c|c|c|c|c|c|}
\hline VARIABLES & Observation & Mean & Std.Dev. & Min & Max \\
\hline Real GDP per capita growth & 469 & 1.391 & 6.345 & -42.930 & 42.579 \\
\hline Real GDP per capita (US dollars) & 509 & $1.410^{14}$ & $2.4910^{15}$ & $2.7210^{9}$ & $5.2010^{16}$ \\
\hline FDI over GDP & 527 & 2.209 & 3.468 & -4.260 & 33.365 \\
\hline FDI (US dollars) & 508 & 1640.88 & 4059.67 & 1174.9 & 39455.9 \\
\hline SIZE & 456 & 18.389 & 7.434 & 4.835 & 76.222 \\
\hline $\mathrm{DI}$ & 438 & 21.891 & 5.936 & 5.539 & 44.058 \\
\hline INF & 473 & 1.819 & 1.372 & -2.862 & 6.608 \\
\hline $\mathrm{EXCH}$ & 532 & 4.158 & 0.543 & 2.092 & 6.206 \\
\hline POP & 529 & 2.175 & 1.448 & -1.083 & 4.415 \\
\hline TRD & 532 & -0.003 & 2.261 & -5.643 & 3.924 \\
\hline $\mathrm{CP}$ & 532 & -0.235 & 2.806 & -3.616 & 8.108 \\
\hline LAW & 532 & 3.684 & 1.332 & 1 & 6 \\
\hline CORP & 524 & 2.505 & 0.896 & 1 & 5 \\
\hline socio & 517 & 5.699 & 2.084 & 5 & 11 \\
\hline INVP & 532 & 7.098 & 2.422 & 1 & 11.5 \\
\hline EXTC & 532 & 8.568 & 2.294 & 2 & 12 \\
\hline DEMO & 524 & 2.704 & 1.439 & 0.416 & 6 \\
\hline GOVS & 531 & 8.065 & 2.334 & 1 & 11.5 \\
\hline INTC & 528 & 7.951 & 2.756 & 1.666 & 12 \\
\hline MILP & 487 & 3.546 & 1.530 & 0.083 & 10.5 \\
\hline BUR & 512 & 1.945 & 0.733 & 0.083 & 4 \\
\hline RELP & 514 & 3.274 & 1.465 & 0.083 & 10.5 \\
\hline ЕСТH & 516 & 3.830 & 1.475 & 0.083 & 6 \\
\hline
\end{tabular}

Table 3: Correlation Matrix of Institutional Measures

\begin{tabular}{|c|c|c|c|c|c|c|c|c|c|c|c|c|}
\hline & (1) & (2) & (3) & (4) & (5) & (6) & (7) & (8) & (9) & (10) & (11) & (12) \\
\hline LAW (1) & 1.000 & & & & & & & & & & & \\
\hline CORP (2) & -0.021 & 1.000 & & & & & & & & & & \\
\hline SOCIO (3) & 0.421 & 0.017 & 1.000 & & & & & & & & & \\
\hline INVP (4) & 0.548 & -0.176 & 0.536 & 1.000 & & & & & & & & \\
\hline EXTC (5) & 0.534 & 0.033 & 0.291 & 0.415 & 1.000 & & & & & & & \\
\hline DEMO (6) & 0.006 & 0.233 & -0.114 & 0.014 & -0.071 & 1.000 & & & & & & \\
\hline GOVS (7) & 0.600 & -0.250 & 0.362 & 0.625 & 0.557 & -0.202 & 1.000 & & & & & \\
\hline INTC (8) & 0.703 & -0.090 & 0.418 & 0.407 & 0.686 & -0.170 & 0.671 & 1.000 & & & & \\
\hline MILP (9) & 0.407 & 0.058 & 0.486 & 0.408 & 0.373 & -0.080 & 0.348 & 0.409 & 1.000 & & & \\
\hline BUR (10) & 0.313 & 0.370 & 0.259 & 0.232 & 0.118 & 0.456 & -0.008 & 0.028 & 0.369 & 1.000 & & \\
\hline RELP (11) & 0.335 & -0.132 & 0.311 & 0.345 & 0.430 & -0.210 & 0.481 & 0.495 & 0.420 & -0.056 & 1.000 & \\
\hline ECTH (12) & 0.449 & -0.193 & 0.282 & 0.345 & 0.479 & -0.217 & 0.553 & 0.686 & 0.284 & -0.168 & 0.270 & 1.000 \\
\hline
\end{tabular}

0.7. We conclude the absence of bi-variable multicolinearity.

\subsection{Methodology and Major Results}

The estimation procedure for the PSTR model consists of eliminating the individual effects $\mu_{\mathrm{i}}$ by removing country-specific means and applying nonlinear least squares $(\mathrm{NLS})^{1}$ to the transformed

\footnotetext{
${ }^{1}$ For more details, see Hansen (1999) and Gonzalez et al. (2005).
}

model. Gonzales et al. (2005) propose a testing procedure in order to test linearity against the PSTR model and determine the number $r$ of transition functions. For the linearity test, the null hypothesis can be written as: $\left\{H_{0}: \gamma=0\right.$.

In both cases the test is non-standard, since the PSTR model contains unidentified nuisance parameters under the null hypothesis. The solution is to replace the transition function $\mathrm{G}\left(\mathrm{z}_{\mathrm{it-d}} ; \gamma, c\right)$ by its firstorder Taylor expansion around $\gamma=0$. To Test 
Table 4: LM Fisher Linearity Test ${ }^{1}$

\begin{tabular}{|c|c|c|c|c|c|c|}
\hline Delay $^{2}$ & d1 & d2 & d3 & d4 & d5 & d6 \\
\hline \hline LAW & $26.936(0.000)$ & $11.348(0.00)$ & $0.881(0.450)$ & $2.953(0.032)$ & $0.383(0.765)$ & $2.018(0.111)$ \\
CORP & $3.996(0.000)$ & $15.484(0.000)$ & $14.188(0.000)$ & $8.605(0.000)$ & $4.971(0.002)$ & $2.274(0.079)$ \\
SOCIO & $2.198(0.087)$ & $2.529(0.056)$ & $1.642(0.179)$ & $3.851(0.009)$ & $3.223(0.022)$ & $1.723(0.162)$ \\
INVP & $4.233(0.005)$ & $5.608(0.000)$ & $0.927(0.427)$ & $0.491(0.688)$ & $4.752(0.002)$ & $1.042(0.374)$ \\
EXTC & $6.263(0.000)$ & $8.700(0.000)$ & $0.951(0.415)$ & $0.088(0.966)$ & $0.109(0.954)$ & $0.679(0.564)$ \\
DEMO & $4.888(0.002)$ & $3.348(0.019)$ & $0.876(0.453)$ & $0.347(0.791)$ & $1.547(0.201)$ & $1.687(0.169)$ \\
GOVS & $50.732(0.000$ & $19.375(0.000)$ & $13.703(0.000)$ & $1.847(0.138)$ & $0.424(0.735)$ & $0.396(0.755)$ \\
INTC & $2.377(0.069)$ & $2.476(0.061)$ & $1.291(0.276)$ & $2.124(0.096)$ & $4.242(0.005)$ & $5.732(0.000)$ \\
MILP & $50.020(0.000)$ & $30.879(0.000)$ & $12.283(0.000)$ & $5.894(0.000)$ & $4.368(0.004)$ & $3.110(0.026)$ \\
BUR & $449.049(0.000)$ & $361.400(0.000)$ & $10.007(0.000)$ & $5.320(0.001)$ & $2.191(0.088)$ & $4.276(0.005)$ \\
RELP & $14.375(0.000)$ & $12.384(0.000)$ & $8.523(0.000)$ & $9.476(0.000)$ & $7.917(0.000)$ & $3.361(0.019)$ \\
ECTH & $11.766(0.000)$ & $2.588(0.052)$ & $3.330(0.019)$ & $0.103(0.958)$ & $0.029(0.993)$ & $0.232(0.873)$ \\
\hline
\end{tabular}

${ }^{1}$ The Wald LM and the Likelihood ratio tests confirm the results of Fisher LM test.

${ }^{2}$ The optimal lag length for the transition variable.

$\mathrm{H}_{0}$ : linear model Vs $\mathrm{H}_{1}$ : PSTR model with at least one threshold.

The numbers in parentheses are $p$ - values of F-statistics.

$H_{0}: \gamma=0$, we will use in this study the Fisher LM test ${ }^{2}$ : $L M_{F}=\left[\left(S S R_{0}-S S R_{1}\right) / K\right] /\left[S S R_{0} /(N T-N-K)\right] ;$ where $S S R_{0}$ is the panel sum of squared residuals under $\mathrm{H}_{0}$ (i.e., linear panel model with individual effects) and $S S R_{1}$ is the panel sum of squared residuals under $\mathrm{H}_{1}$ (i.e., PSTR model with two regimes). $\mathrm{K}$ is the number of explanatory variables, and it has an approximate $F(K, N T-N-K)$ distribution.

Referring to the LM test in Table 4, the null hypothesis that the model is linear is rejected at the $1 \%$ level for transition variables. We conclude that the relationship between institutions and growth is nonlinear. Therefore, a PSTR model is used to estimate that relationship. After fixing the delay, Teräsvirta (1994) proposes a short sequence of ordinary Fisher test to decide between PESTR and PLSTR family of models (Table 5).

Once the linearity test and the test of the choice between PESTR and PLSTR are used, the problem is to identify the number of transition functions. The methodology of sequential tests is generally used. In general, a PSTR with $r^{*}$ transition functions, we test the null hypothesis $\left(\mathrm{H}_{0}: r=r^{*}\right.$ against $\left.\mathrm{H}_{1}: r=r^{*}+1\right)$. If $\mathrm{H}_{0}$ is not rejected, the procedure ends. Otherwise, $H_{0}: r=r^{*}+1$ is tested against $H_{1}: r=r^{*}+2$. The testing

\footnotetext{
${ }^{2}$ To test linearity, there are also the Wald LM test: $L M_{W}=N T\left(S S R_{0}-S S R_{1}\right) / S S R_{0}$ and the pseudo- Likelihood ratio test: pseudo$L R=-2\left(\log S S R_{1}-\log S S R_{0}\right)$ distributed as $\chi^{2}(k)$ under the null hypothesis.
}

procedure continues until the first acceptance of the null hypothesis. The issue is to test whether there is one transition function $\left(H_{0}: r=1\right)$, or whether there are at least two transition functions $\left(\mathrm{H}_{1}: \mathrm{r}=2\right)$.

According to the test of no remaining nonlinearity the F-statistic $L M_{F}$, we find that the model with one threshold (two regimes) adequately captures the nonlinear relationship. A weak number of transition functions are sufficient to assess the non-linearity. Thus, a PSTR model with one transition function seems to be appropriate in this study (Table 6).

Table 7 presents PSTR estimates of Eq (6) using the NLS method for the 12 models. We conclude that all control variables have the expected sign. We find an instable direct impact of FDI on growth, measured by $\alpha_{0}$, insignificant in all regressions, with one exception when the threshold variable is Military in politics (MILP). Also, we find for all transition variables, FDIeconomic growth coefficient $\alpha_{1}$ is positive and only statistically significant for Socioeconomic conditions $(\mathrm{SOClO})$ variable with values ranging between 0.006 and 3.794. This implies that an increase of the transition variables entails an increase of FDI-growth coefficient. In Countries with high level of institutions, there is positive effect of FDI on economic growth.

We found that the shift between the two extreme regimes occurs around the location parameter $\mathrm{c}$ (the 12 location parameters seem far from their respective mean values reported in Table 1). We conclude that only countries with good institutions can exploit the advantages of FDI on growth. The slope appears to be sharp for Investment profile (INVP), Democratic 
Table 5: Sequence test of Fisher: Choice between PESTR and PLSTR

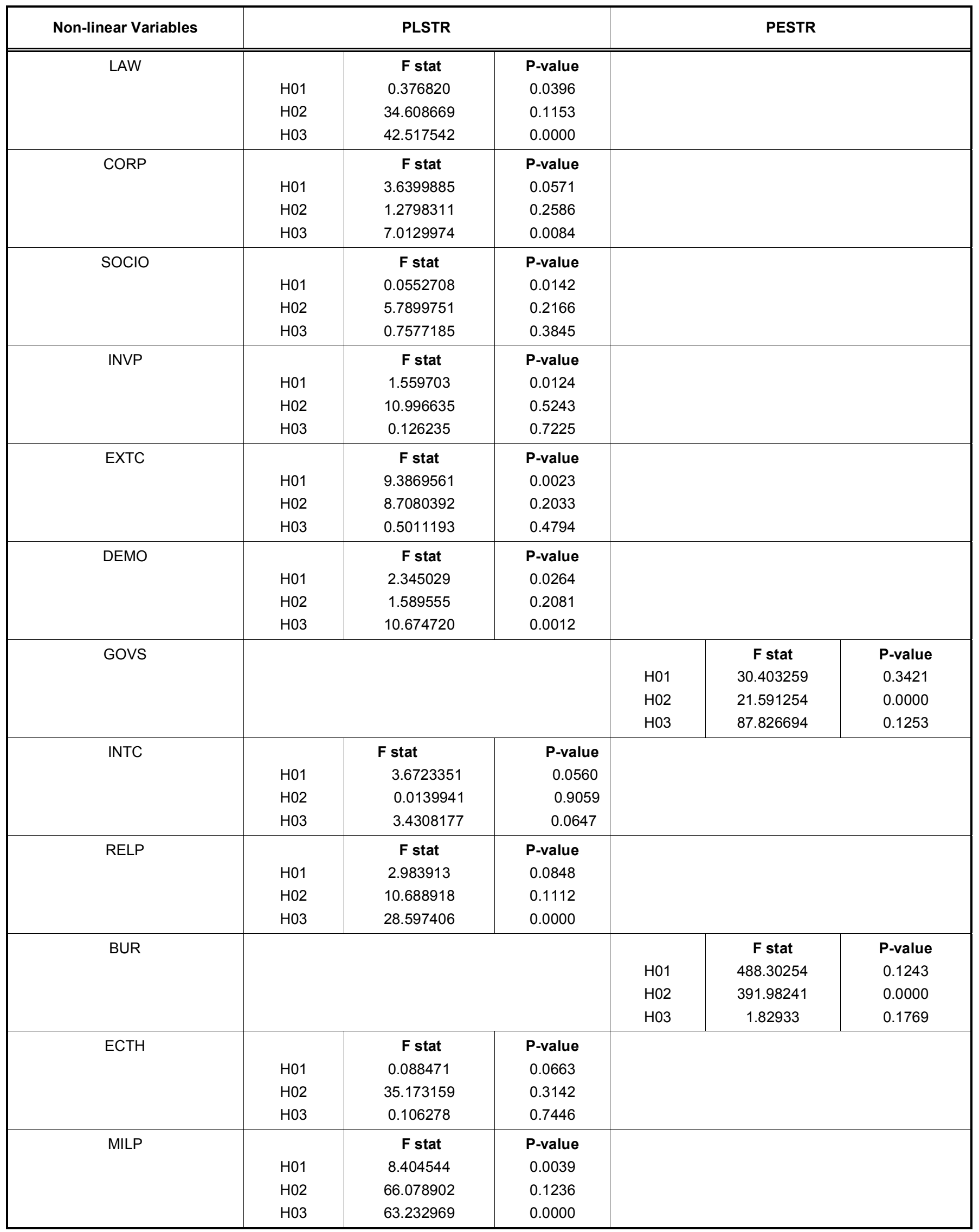

The numbers in parentheses are P-values of F-statistics. Statistics are reported until the non-rejection of $\mathrm{H}_{0}$ 
Table 6: No Remaining Nonlinearity Test

\begin{tabular}{|c|c|c|}
\hline $\begin{array}{l}\text { Transition } \\
\text { Variables }\end{array}$ & $\begin{array}{c}H_{0}: 1 \text { regime (no transition function) } \\
\text { vs } \\
H_{0}: 2 \text { regimes (1 transition function) }\end{array}$ & $\begin{array}{c}H_{0}: 2 \text { regimes ( } 1 \text { transition function) } \\
\text { vs } \\
H_{0}: 3 \text { regimes (2 transition function) }\end{array}$ \\
\hline CORP & $F=152.159801(0.000)$ & $F=0.237512(0.873164)$ \\
\hline SOCIO & $F=54.675632(0.000)$ & $F=0.135312(0.9215342)$ \\
\hline EXTC & $F=40.426303(0.000)$ & $F=0.25124123(0.94153241)$ \\
\hline DEMO & $F=129.142938(0.000)$ & $F=0.5197413(0.97416322)$ \\
\hline GOVS & $F=33.412432(0.000)$ & $F=0.062312(0.999321323)$ \\
\hline INTC & $F=57.680642(0.000)$ & $F=0.964213(0.9985312)$ \\
\hline MILP & $F=122.749673(0.000)$ & $F=0.862134(0.9993123)$ \\
\hline
\end{tabular}

accountability (DEMO) and Government stability (GOVS) (77.734, 30.240 and 30.236 respectively). We conclude for those indicators that the transition is rather rough and the PTR framework of Hansen (1999) is indicated to assess FDI-growth nexus the slope parameter tends towards the infinity. This implies that an effort by MENA country just below the threshold value of 0.006 ( 0.206 and 0.206 respectively) is likely to result in a sharp increase of the elasticity of growth with respect to FDI, from 0.0 to 0.006 respectively. For Law and order (LAW), Corruption (CORP), Socioeconomic conditions (SOCIO), External conflicts (EXTC), Internal conflicts (INTC), Military in politics (MILP), Bureaucracy quality (BUR), Religion in politics (RELP) and Ethnic tension (ECTH), we find a smooth transition and consequently the PSTR is well adapted because the slopes of transition functions are low (the highest value is 3.350 for Law and order). It means that conditionally to those variables, the relationship between FDI and growth cannot be reduced to a limited number of regimes.

This result, so far, confirms the idea that FDl's growth is enhanced only in countries with a low level of corruption. We point out that high quality of institutions in host countries influence FDI and consequently growth. When institutions are strong, the legal system works effectively and attracts FDI. The share of FDI is higher in countries with strong institutions. We conclude that FDI and institutions go hand in hand and FDI is fostered by the effectiveness of institutions. This illustrates clearly that an improvement of those indicators will lead to a greater increase in the growth impact of FDI because they have an immediate potential for fostering FDI-economic growth impact. MENA countries need to achieve a minimum level of institutional quality in order to benefit from the advantages offered by FDI. Over all, the main result of this study is that it shows that a better contribution of FDI to economic growth requires taking into account the interrelationship and the complementarity between FDI and institutions.

\section{CONCLUDING REMARKS AND FUTURE LINES}

Motivated by the important role of FDI for economic growth, this paper has shed new light on understanding this relationship by focusing on the role played by the institutional quality in host countries. Using a panel of 19 MENA countries for the period 1984-2011, this paper highlights the impact of FDI on economic growth conditional on the institutional quality. The empirical evidence captured by within the PSTR approach confirms that institutional quality clearly influences the impact of FDI on growth in MENA countries. The PSTR is adopted for 9 measures of institutions quality (Law and order, Corruption, Socioeconomic conditions, External conflicts, Internal conflicts, Military in politics, Bureaucracy quality, Religion in politics and Ethnic tension).

The results suggest that public authorities in MENA countries must build appropriate institutions to attract 


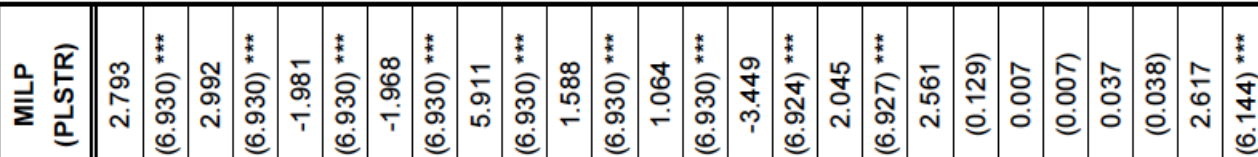

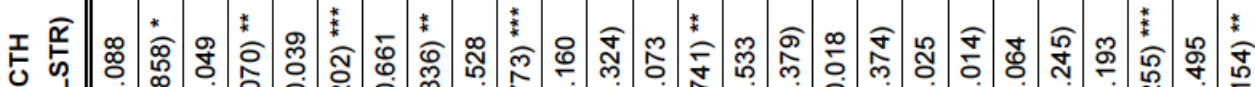

W

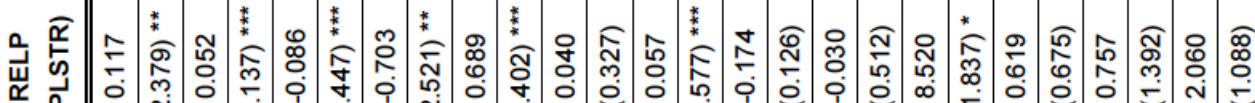

ए

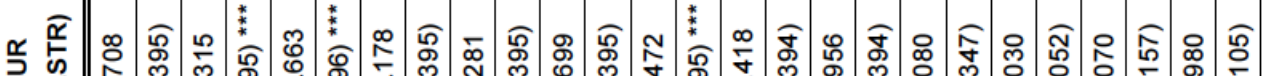

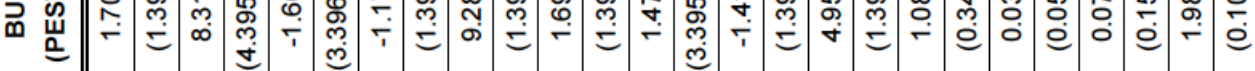

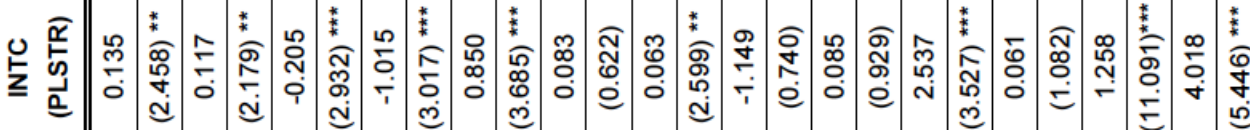

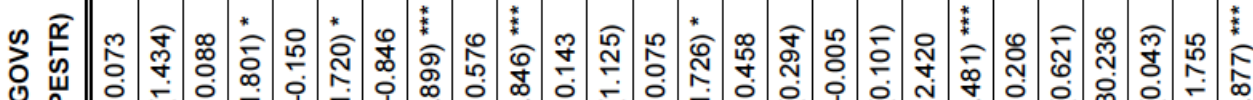

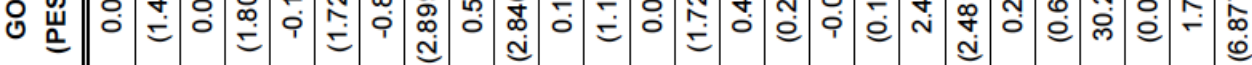

列

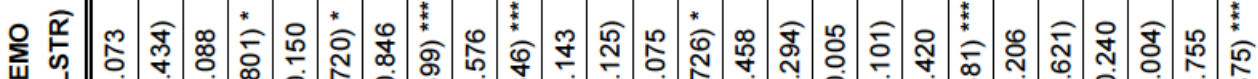

至

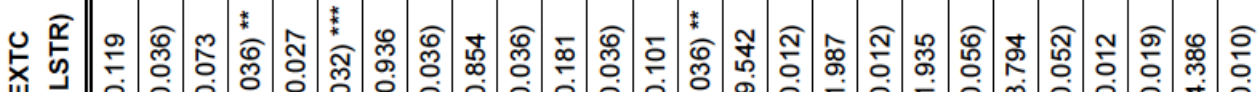

世

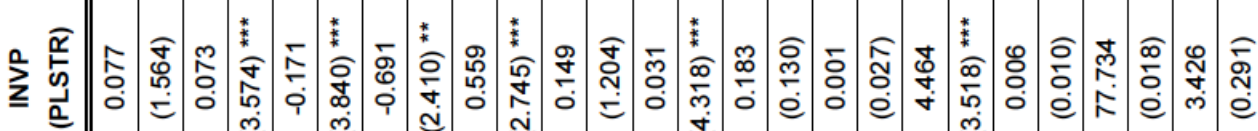

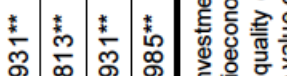

サ่

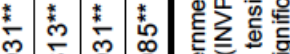

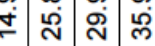

*

Sִ

サं

* * * *

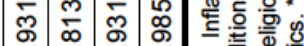

广

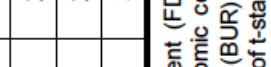

* * * *

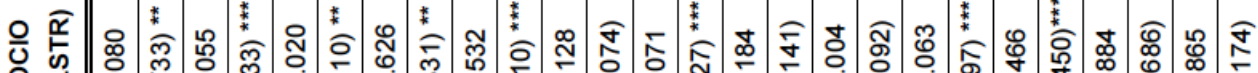

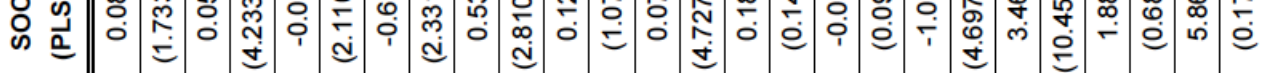

ळ.

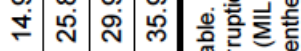

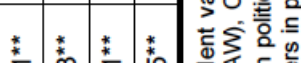

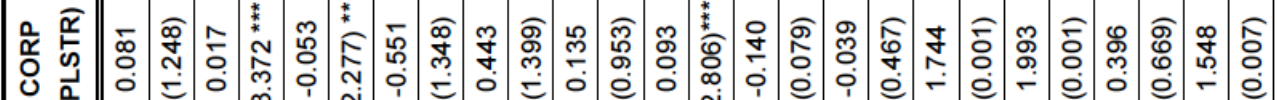

-

广ं

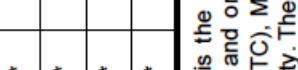

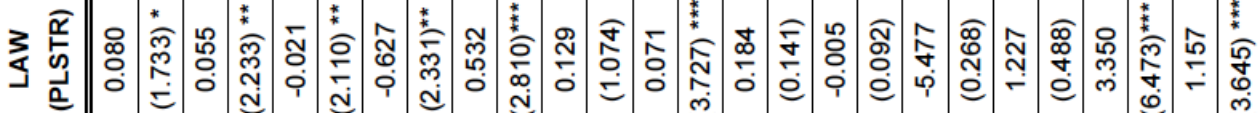

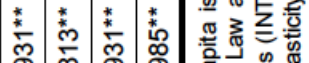

广

ナ ब范

욘

苑

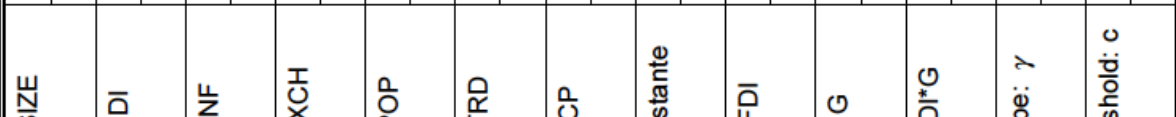

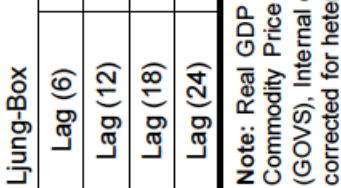




\section{Appendix 1: Data Measurement}

\begin{tabular}{|c|c|c|}
\hline Variables & Definition & Source \\
\hline Growth (GDP) & Real GDP per capita & World Development Indicators \\
\hline FDI (FDI) & Net inflows of Foreign direct investment & World Development Indicators \\
\hline Inflation (INF) & Change in consumer price index & World Development Indicators \\
\hline Trade (TRD) & Import plus export divided to GDP & World Development Indicators \\
\hline Government size (SIZE) & Ratio of Government final consumption to GDP & World Development Indicators \\
\hline Population (POP) & Growth rate of total population & World Development Indicators \\
\hline Domestic Investment (PI) & Gross fixed capital formation as a share of GDP & World Development Indicators \\
\hline Exchange rate $(\mathrm{EXCH})$ & Real Effective Exchange rate & DataStream \\
\hline Commodity Price (CP) & Commodity Price Index $(2000=100)$ & UNCTAD \\
\hline Law and order (LAW) & $\begin{array}{l}\text { Measure of the law and order tradition of a country. It ranges from } 6 \text {, } \\
\text { strong law and order tradition, to } 1 \text {, weak law and order tradition. }\end{array}$ & $\begin{array}{l}\text { International Country Risk Guide } \\
\text { (ICRG) }\end{array}$ \\
\hline Corruption (CORP) & $\begin{array}{l}\text { The level of corruption ranges from } 1 \text { (high level of corruption) to } 5 \\
\text { (low level). }\end{array}$ & $\begin{array}{l}\text { International Country Risk Guide } \\
\text { (ICRG) }\end{array}$ \\
\hline $\begin{array}{l}\text { Socioeconomic conditions } \\
\text { (SOCIO) }\end{array}$ & $\begin{array}{l}\text { This is an assessment of the socioeconomic pressures at work in } \\
\text { society that could constrain government action or fuel social } \\
\text { dissatisfaction. The risk rating assigned is the sum of three } \\
\text { subcomponents, each with a maximum score of four points and a } \\
\text { minimum score of } 0 \text { points. A score of } 4 \text { points equates to Very Low } \\
\text { Risk and a score of } 0 \text { points to Very High Risk. }\end{array}$ & $\begin{array}{l}\text { International Country Risk Guide } \\
\text { (ICRG) }\end{array}$ \\
\hline Investment profile (INVP) & $\begin{array}{l}\text { This is an assessment of factors affecting the risk to investment that } \\
\text { are not covered by other political, economic and financial risk } \\
\text { components. The risk rating assigned is the sum of three } \\
\text { subcomponents, each with a maximum score of four points and a } \\
\text { minimum score of } 0 \text { points. A score of } 4 \text { points equates to Very Low } \\
\text { Risk and a score of } 0 \text { points to Very High Risk. }\end{array}$ & $\begin{array}{l}\text { International Country Risk Guide } \\
\text { (ICRG) }\end{array}$ \\
\hline External conflicts (EXTC) & $\begin{array}{l}\text { The external conflict measure is an assessment both of the risk to } \\
\text { the incumbent government from foreign action, ranging from non- } \\
\text { violent external pressure (diplomatic pressures, withholding of aid, } \\
\text { trade restrictions, territorial disputes, sanctions, etc) to violent } \\
\text { external pressure (cross-border conflicts to all-out war). The risk } \\
\text { rating assigned is the sum of three subcomponents, each with a } \\
\text { maximum score of four points and a minimum score of } 0 \text { points. A } \\
\text { score of } 4 \text { points equates to Very Low Risk and a score of } 0 \text { points to } \\
\text { Very High Risk. }\end{array}$ & $\begin{array}{l}\text { International Country Risk Guide } \\
\text { (ICRG) }\end{array}$ \\
\hline $\begin{array}{l}\text { Democratic accountability } \\
\text { (DEMO) }\end{array}$ & $\begin{array}{l}\text { This is a measure of how responsive government is to its people, on } \\
\text { the basis that the less responsive it is, the more likely it is that the } \\
\text { government will fall, peacefully in a democratic society, but possibly } \\
\text { violently in a non-democratic one. }\end{array}$ & $\begin{array}{l}\text { International Country Risk Guide } \\
\text { (ICRG) }\end{array}$ \\
\hline $\begin{array}{l}\text { Government stability } \\
\text { (GOVS) }\end{array}$ & $\begin{array}{l}\text { This is an assessment both of the government's ability to carry out } \\
\text { its declared program(s), and its ability to stay in office. The risk rating } \\
\text { assigned is the sum of three subcomponents, each with a maximum } \\
\text { score of four points and a minimum score of } 0 \text { points. A score of } 4 \\
\text { points equates to Very Low Risk and a score of } 0 \text { points to Very High } \\
\text { Risk. }\end{array}$ & $\begin{array}{l}\text { International Country Risk Guide } \\
\text { (ICRG) }\end{array}$ \\
\hline Internal conflicts (INTC) & $\begin{array}{l}\text { This is an assessment of political violence in the country and its } \\
\text { actual or potential impact on governance. The highest rating is given } \\
\text { to those countries where there is no armed or civil opposition to the } \\
\text { government and the government does not indulge in arbitrary } \\
\text { violence, direct or indirect, against its own people. The lowest rating } \\
\text { is given to a country embroiled in an on-going civil war. The risk } \\
\text { rating assigned is the sum of three subcomponents, each with a } \\
\text { maximum score of four points and a minimum score of } 0 \text { points. A } \\
\text { score of } 4 \text { points equates to Very Low Risk and a score of } 0 \text { points to } \\
\text { Very High Risk. }\end{array}$ & $\begin{array}{l}\text { International Country Risk Guide } \\
\text { (ICRG) }\end{array}$ \\
\hline Militay in politics (MILP) & $\begin{array}{l}\text { The military is not elected by anyone. Therefore, its involvement in } \\
\text { politics, even at a peripheral level, is a diminution of democratic } \\
\text { accountability. However, it also has other significant implications. }\end{array}$ & $\begin{array}{l}\text { International Country Risk Guide } \\
\text { (ICRG) }\end{array}$ \\
\hline
\end{tabular}




\begin{tabular}{|c|c|c|}
\hline $\begin{array}{l}\text { Bureaucracy quality } \\
\text { (BUR) }\end{array}$ & $\begin{array}{l}\text { The institutional strength and quality of the bureaucracy is another } \\
\text { shock absorber that tends to minimize revisions of policy when } \\
\text { governments change. Therefore, high points are given to countries } \\
\text { where the bureaucracy has the strength and expertise to govern } \\
\text { without drastic changes in policy or interruptions in government } \\
\text { services. In these low-risk countries, the bureaucracy tends to be } \\
\text { somewhat autonomous from political pressure and to have an } \\
\text { established mechanism for recruitment and training. }\end{array}$ & $\begin{array}{l}\text { International Country Risk Guide } \\
\text { (ICRG) }\end{array}$ \\
\hline Religion in politics (RELP) & $\begin{array}{l}\text { Religious tensions may stem from the domination of society and/or } \\
\text { governance by a single religious group that seeks to replace civil law } \\
\text { by religious law and to exclude other religions from the political } \\
\text { and/or social process; the desire of a single religious group to } \\
\text { dominate governance; the suppression of religious freedom; the } \\
\text { desire of a religious group to express its own identity, separate from } \\
\text { the country as a whole. }\end{array}$ & $\begin{array}{l}\text { International Country Risk Guide } \\
\text { (ICRG) }\end{array}$ \\
\hline Ethnic tension (ECTH) & $\begin{array}{l}\text { This component is an assessment of the degree of tension within a } \\
\text { country attributable to racial, nationality, or language divisions. } \\
\text { Lower ratings are given to countries where racial and nationality } \\
\text { tensions are high because opposing groups are intolerant and } \\
\text { unwilling to compromise. Higher ratings are given to countries where } \\
\text { tensions are minimal, even though such differences may still exist. }\end{array}$ & $\begin{array}{l}\text { International Country Risk Guide } \\
\text { (ICRG) }\end{array}$ \\
\hline
\end{tabular}

more FDI flows and consequently increase the rate of economic growth. Also, they should promote the international integration of MENA countries in Europe and Asia. A good understanding in host countries of the positive externality of $\mathrm{FDI}$ on growth requires the complement and the interrelationship between institutions and FDI.

As a future line of research, it would be valuable to investigate more in-depth the effects of institutions quality on the growth-FDI nexus in emerging and developed countries.

\section{ACKNOWLEDGEMENTS}

The authors are grateful to the Editor-in-chief and the anonymous referees of this journal for their discussions and comments on an earlier version of this paper. Suggestions and comments from participants of "10th EBES Conference" (Istanbul June 2014) and " 6 "th World Conference on Educational Sciences" (Malta February 2014) are gratefully acknowledged.

\section{REFERENCES}

Ali, F., Fiess, N., and MacDonald, R. 2010. "Do institutions matter for foreign direct investment?" Open Economies Review 21(2): 201-219. http://dx.doi.org/10.1007/s11079-010-9170-4

Ali, Fathi A. (2010). "Essays on foreign direct investment, institutions, and economic growth." PhD thesis, University of Glasgow.

Bénassy-Quéré, A., Coupet, M., Mayer, T., 2007. "Institutional Determinants of Foreign Direct Investment ". World Economy: 1-19.

Blomström, M., and Kokko, A. 2003. "The economics of foreign direct investment incentives." NBER Working Paper No. 9489, Cambridge, MA: NBER.
Bowen, H.P., and Wiersema, M. F. 2005. "Foreign-based competition and corporate diversification strategy." Strategic Management Journal 26(13): 1153-1171. http://dx.doi.org/10.1002/smj.499

Busse, M., and Hefeker, C. 2007. "Political risk and foreign direct investment." European Journal of Political Economy. 23: 397415. http://dx.doi.org/10.1016/j.ejpoleco.2006.02.003

Chen, M.-J., Su, K., and Tsai, W. 2007. "Competitive tension: The awareness-motivation-capability perspective." Academy of Management Journal, 50, 101-118. http://dx.doi.org/10.5465/AMJ.2007.24162081

Daniele, V., and Marani, U, 2007. "Do institutions matter for FDI? A comparative analysis for the MENA countries." MPRA Paper. $2426,1-28$.

Daude, C., and Stein, E. 2007. "The quality of institutions and foreign direct investment." Journal of Economic and Politics. 19(3): 317-344. http://dx.doi.org/10.1111/j.1468-0343.2007.00318.x

Driffield, N., and Love, J.H. 2007. "Linking FDI motivation and host economy productivity effects: Conceptual and empirical analysis." Journal of International Business Studies 38(3): 460-473. http://dx.doi.org/10.1057/palgrave.jibs.8400268

Dunning, J. H. (1988). "The Eclectic Paradigm of International Production: A Restatement and Some Possible Extensions " Journal of International Business Studies, Vol. 19 No. 1 Spring, pp. 1-31. http://dx.doi.org/10.1057/palgrave.jibs.8490372

Gonzalez, A., Terasvirta, T., and van Dijk, D., 2005. "Panel Smooth Transition Regression Models." SSE/EFI Working Paper Series in Economics and Finance, No. 604, pp 1-32.

Guerin, S.S., and Manzocchi, S. 2009. "Political Regime and FDI from Advanced to Emerging Countries." Review of World Economics 145(1): 75-91. http://dx.doi.org/10.1007/s10290-009-0004-7

Habib, M., and Zurawicki, L. 2002. "Corruption and Foreign Direct Investment", Journal of International Business Studies, Vol. $33, \mathrm{~N}^{\circ} 2$, pp. 291-307. http://dx.doi.org/10.1057/palgrave.jibs. 8491017

Hansen, B. E., 1999. "Threshold effects in non-dynamic panels: estimation, testing and inference." Journal of Econometrics 93: 334-368. http://dx.doi.org/10.1016/S0304-4076(99)00025-1 
Ibarra, R., and Trupkin, D., 2001. "The Relationship between Inflation and Growth: A Panel Smooth Transition Regression Approach for Developed and Developing Countries." BCU, No. 6: pp 1-23.

Jude, C., and Levieuge, G., 2013. "Growth effect of FDI in developing economies: the role of institutional quality." MPRA, No. 49321: pp 1-31.

Kohler, P., 2010. "Foreign direct investment in countries with weak institutions." WP, Group World Economic: pp 1-31.

Ljung, G. M., and Box, G. E. P., 1978. "On a Measure of a Lack of Fit in Time Series Models." Biometrika 65: pp 297-303. http://dx.doi.org/10.1093/biomet/65.2.297

Lundvall, B.A., Johnson, B., Andersen, E.S., and Dalum, B. 2002. "National systems of production." innovation and competence building, Research Policy 31(2): pp 213- 231 http://dx.doi.org/10.1016/S0048-7333(01)00137-8

Méon, P-G., and Sekkat, K. 2008. "Institutional quality and trade: Which institutions? Which trade?" Economic Inquiry 46(2): pp 227-240. http://dx.doi.org/10.1111/j.1465-7295.2007.00064.x

Méon, P-G., and Sekkat, S. 2004. "Does the quality of the institutions limit the MENA's Integration in the World Economy?" World Economy: pp 1475-1498.

http://dx.doi.org/10.1111/j.0378-5920.2004.00661.x

Mody, A., and Murshid, A. 2005. "Growing up with capital flows." Journal of International Economics 65(1): 249-266. http://dx.doi.org/10.1016/j.jinteco.2004.02.003

Morrissey, O., and Udomkerdmongkol, M. 2012. "Governance, private investment and foreign direct investment in developing countries." World Development 40(3): 437-45. http://dx.doi.org/10.1016/j.worlddev.2011.07.004
Nelson, R.R. 1993. "National systems of innovation." Oxford: Oxford University Press.

Ng, S., and Perron, P., 1995. "Unit Root Tests in ARMA Models with Data-Dependent Methods for the Selection of the Truncation Lag." Journal of the American Statistical Association, 90: 268-281. http://dx.doi.org/10.1080/01621459.1995.10476510

North, D. 1990. "Institutions, Institutional Change and Economic Performance." Cambridge.

Onyeiwu, S., 2003. "Analysis of FDI flows to Developing countries: Is the MENA region different?" ERF $10^{\text {th }}$ annual conference Marrakech Morocco, December, pp.1-22.

Peng, M.W., Wang, D.Y.L., and Jiang, Y. 2008. "An Institution-based on view of international business strategy: A focus on emerging economies." Journal of International Business Studies 39(5): pp 920-936. http://dx.doi.org/10.1057/palgrave.jibs. 8400377

Teräsvirta T., 1994. "Specification, estimation, and evaluation of smooth transition Autoregressive models." Journal of the American Statistical Association, 89: pp 208-218.

Voyer P.A., and Beamish P.W. 2004. "The Effect of Corruption on Japanese Foreign Direct Investment", Journal of Business Ethics, Vol. 50, pp. 211-224. http://dx.doi.org/10.1023/B:BUSI.0000024737.57926.bf

Wei, S-J. 1997. "Why is corruption so much more taxing than tax? Arbitrariness kills. "NBER Working Paper 6255.

Wei, S-J. 2000. "How taxing is corruption to international investors?"Review of Economics and Statistics 82: 1-11. http://dx.doi.org/10.1162/003465300558533

\section{DOI: http://dx.doi.org/10.6000/1929-7092.2014.03.24}

(C) 2014 Brahim and Rachdi; Licensee Lifescience Global.

This is an open access article licensed under the terms of the Creative Commons Attribution Non-Commercial License (http://creativecommons.org/licenses/by-nc/3.0/) which permits unrestricted, non-commercial use, distribution and reproduction in any medium, provided the work is properly cited. 